\title{
LEXICON
}

\author{
VOLUME 3 \\ Number 2, October 2014 \\ Page 166-178
}

\section{INDIRECT REFUSAL STRATEGIES IN TWO AMERICAN AND THREE BRITISH MOVIES}

\author{
Curtina Melati Kasih
}

\begin{abstract}
This research focuses on identification and classification of indirect refusal strategies found in two American movies (RV (2006), We're the Millers (2014)) and three British movies (Chalet Girl (2011), Cuban Fury (2014), and Hot Fuzz (2007)). In particular, it aims to show the different strategy between the refusals of American and British movies. The data were analysed by FélixBrasdefer taxonomy of indirect refusal strategies $(2008,74-79)$. The data used in this research were taken through an observation from the subtitle of these five movies. The results of the research show that out of the 92 refusal utterances, 50 were found in the American movies and 42 from the British movies. Based on the findings, the most frequently used strategy from the American movies is Strategy 1: Mitigated Refusal. This strategy was used 11 times (11.96\%). In the British movies, the most common strategy is Strategy 2: Reason/Explanation which used 17 times (18.48\%). These results suggest that the American and the British have their own ways in delivering refusal. To minimize the negative effects of being refused the American tends to hedge the refusal for making the utterances sounds more polite. Meanwhile, the British tends to explain why they cannot fulfil the interlocutor's demand.
\end{abstract}

Keywords: indirect refusal, mitigated refusal strategy, reason/explanation strategy, American and British movies

\section{INTISARI}

Penelitian ini berfokus pada identifikasi dan klasifikasi strategi penolakan tidak langsung yang ditemukan di dua film Amerika (RV (2006), We're the Millers (2014)) dan tiga film Inggris (Chalet Girl (2011), Cuban Fury (2014), dan Hot Fuzz (2007)). Secara khusus, penelitian ini bertujuan untuk menunjukkan perbedaan strategi penolakan yang digunakan di film-film Amerika dan Inggris. Data dianalisis dengan teori pengelompokkan strategi penolakan tidak langsung oleh Félix-Brasdefer (2008, 74-79). Data yang digunakan dalam penelitian ini diambil melalui observasi dari subtitle kelima film tersebut. Hasil penelitian ini menunjukkan bahwa dari 92 ungkapan penolakan, 50 ditemukan dalam film Amerika dan 42 dalam film Inggris. Berdasarkan hasil dari penelitian, penggunaan strategi penolakan tidak langsung terbanyak dari film Amerika adalah strategi 1: Mitigated Refusal. Strategi ini digunakan sebanyak 11 kali 
(11.96\%). Di dalam film Inggris, strategi yang paling sering digunakan adalah Strategi 2: Reason/ Explanation yaitu 17 kali (18.48\%). Hasil ini menunjukkan bahwa orang Amerika dan Inggris mempunyai cara masing-masing dalam mengungkapkan penolakan. Untuk meminimalisir dampak negatif dari penolakan, orang Amerika cenderung membatasi penolakan untuk membuat ungkapan yang disampaikan terdengar lebih sopan. Sementara itu, orang Inggris cenderung untuk memberikan alasan ketika tidak dapat memenuhi permintaan lawan bicara.

Kata kunci: penolakan tidak langsung, strategi mitigated refusal, strategi reason/explanation, beberapa film Amerika dan Inggris 


\section{INTRODUCTION}

\section{Background of the Study}

American and British English look similar on the surface because they perform the same linguistic code (i.e. English). In spite of their similarities, if examined further, American and British English are slightly different in performing their language. "Differences between American and British English include pronunciation, grammar, vocabulary (lexis), spelling, punctuation, idioms, and formatting of dates and numbers" (Diffen 2014). The differences can even be found in using speech acts.

Refusal is one kind of speech acts that is frequently found in daily life conversations. Refusal can be used in response to requests, invitations, offers, or suggestions. In Cambridge Advanced Learner's Dictionary (2008), refusal means when someone refuses to do or accept something. Sometimes, when people cannot fulfil and directly refuse the interlocutor's demand, it can make the speaker feels disappointed or sad. In order to lessen the negative effects of being refused, the interlocutor can use an indirect way in delivering refusal. Because the more indirect the refusal is uttered, the more polite it sounds.

It is interesting to investigate how American and British deliver indirect refusal in conversations. The researcher wants to find how often indirect refusal strategies used by the characters in the American and British movies and also show the different strategies between the American and British in giving indirect refusals.

\section{Research Goals}

The objectives of the study are to:

1. classify and identify indirect refusal strategies found in American and British movies; and

2. show the different refusal strategies used in American and British movies.

\section{Research Methods}

\section{Data Source}

The data of this research were the English subtitles of these five movies, entitled $R V$ (2006), Hot
Fuzz (2007), Chalet Girl (2011), We're the Millers (2013), and Cuban Fury (2014). The English subtitles of three of the five movies entitled $R V$, We're the Millers and Hot Fuzz were attached, while the English subtitles of the other two movies entitled Cuban Fury and Chalet Girl had to be downloaded from www.subscene.combetween September, 15th16 th, 2014 by the researcher.

\section{Method of Collecting the Data}

The researcher applied several procedures to collect the data. First, the researcher watched the selected movies entitled $R V$, We're the Millers, Chalet Girl, Cuban Fury and Hot Fuzz. While watching each of the five movies, the researcher focused on the indirect refusals to request, invitation, suggestion, and offer made by the characters. When the data were found, the researcher paused the movies, re-read the indirect refusals from the subtitles, wrote the dialogue containing the indirect refusal expressions uttered by the characters, and noted the time duration. The time duration was written when the dialogues started up to the refusals were completely delivered. Last, the data that had been collected were completed by giving important information or description for the interpretation of the dialogue, including the characters (name, age, social distance, social status, etc.), the topic of the refusal, and settings of time and place.

\section{Method of Analyzing the Data}

The data were classified into four functions of refusals (request, suggestion, offer, and invitation). After the indirect refusals were classified into its functions of refusal, the indirect refusals were identified based on the types of indirect refusal strategies following Félix-Brasdefer's taxonomy (FélixBrasdefer 2008, 74-79). They were calculated to determine the frequency of each of indirect refusal strategies in those five movies. The data which contains indirect refusals were coded according to:

1) the time duration when the conversations (containing indirect refusal) occur, 
2) the group of the movies: AM for American Movies and BM for British Movies,

3) the abbreviations of the movie titles: RV for $R V$, WM for We're the Millers, CG for Chalet Girl, CF for Cuban Fury, and HZ for Hot Fuzz.

4) the types of indirect refusal strategies found in the subtitle: \#1 for mitigated refusal, \#2 for reason/explanation, \#3 for indefinite reply, \#4 for apology/regret, \#5 for alternative, \#6 for postponement, \#7 for repetition of part of previous discourse, \#8 for request for additional information, \#9 for set condition for future or past acceptance, \#10 for wish, \#11 for promise to comply, and \#12 for preparator,

5) the number of occurrences of a particular indirect refusal strategy.

\section{Literature Review}

There have been some previous researches about refusal. For example, Burhanuddin (2008) conducted a research about comparison of refusal in English by Indonesian learners and native speakers of English. The finding of his research is that both interlocutors share some similarities in the forms of speech acts in their refusals. Native speakers of English expressed more refusals in single speech act and combination of two speech acts than refusals by Indonesian learners.

Rahmatika (2013) had an indirect refusal research in terms of politeness in 13 American movies. This research uses Brown and Levinson's (1987) politeness theory. She found that the most commonly used positive politeness strategy is offer a promise while the most frequently used negative strategies are be optimistic and state the FTA (Face-Threatening Acts) as a general rule.

Muliawati (2014) did a research focusing on the degree of indirectness in indirect refusals spoken by the characters of the movies Jack and Jill, Letters to Juliet and Real Steel. Her finding shows that reason/explanation is the most commonly used strategy in giving refusals.

Charismawati's research (2014) focused on the negative and positive strategies of refusal pro- duced by the characters in three American drama movies and analysed by using Brown and Levinson's (1987) politeness theory. Her finding shows that the most frequently used positive politeness strategy is give (or ask for) reason while in the negative politeness strategy the most common is be conventionally indirect.

CARLA (Center for Advanced Research on Language Acquisition) (2014) published on its website about the research of American and British refusal. The website concludes that the Americans typically start their refusal by expressing a positive opinion or feeling about the interlocutor's demand. While giving reasons or explanations is the way of the British in delivering their refusal.

Unlike the previous researches, this research aims at investigating how American and British producing their indirect refusals in conversations as reflected in American and British movies. Particularly, this research wants to show what strategies are commonly used by the American and British.

\section{Presentation}

Introduction explains the background of the study, goals, methods, and literature review. Following this section, it presents the identification and classification of the data based on each indirect refusal strategy in American and British movies and discusses the result of the data analysis. Lastly, Conclusion contains the results from the discussion presented and some suggestions for the next research.

\section{DISCUSSION}

\section{The Analysis of Indirect Refusal Strategies in American and British Movies}

This chapter presents identification and classification of the data based on each indirect refusal strategies by Félix-Brasdefer. It also presents the result of the data analysis. There are 92 utterances containing indirect refusal which are taken from American (RV and We're the Millers) and British (Chalet Girl, Cuban Fury, and Hot Fuzz) movies. Table 1 summarises the distribution of the data research. 
Table 1. The Distribution of Indirect Refusals in American and British Movies

\begin{tabular}{|c|c|c|c|c|c|}
\hline No. & Movie Title & Group & no. & $\mathbf{T}$ & $\begin{array}{c}\text { IR/10 } \\
\text { minutes }\end{array}$ \\
\hline 1 & RV & \multirow{2}{*}{$\begin{array}{c}\text { American } \\
\text { Movies }\end{array}$} & 26 & 99 & 2.60 \\
\hline 2 & We're the Millers & & 24 & 110 & 2.18 \\
\hline 3 & Chalet Girl & \multirow{3}{*}{$\begin{array}{l}\text { British } \\
\text { Movies }\end{array}$} & 13 & 97 & 1.34 \\
\hline 4 & Cuban Fury & & 14 & 98 & 1.43 \\
\hline 5 & Hot Fuzz & & 15 & 121 & 1.24 \\
\hline \multicolumn{3}{|c|}{ Total } & 92 & 525 & 8.79 \\
\hline
\end{tabular}

Notes:

IR : indirect refusal

t : film runtime

no. : number of occurrences

The results show that out of the 92 refusal utterances, 26 were found in $R V, 24$ in We're the Millers, 15 in Hot Fuzz, 14 in Cuban Fury, and 13 in Chalet Girl. In average, $R V$ has the most occurrences of 2.60 per 10 minutes. Following $R V$ is We're the Millers which has an average 2.18 occurrence of indirect refusals every 10 minutes. Next, the movie of Hot Fuzz and Chalet Girl which have averages 1.43 and 1.34 per 10 minutes. Cuban Fury has an average of 1.24 refusals per 10 minutes.

\section{TYPES OF INDIRECT REFUSAL}

Following Félix-Brasdefer classification of indirect refusal strategies, these 92 indirect refusals found in the five movies are classified into 12 strategies of indirect refusals. Table 2 presents the results of the data analysis.

Table 2. The Frequency and Distribution of Indirect Refusal Strategies in American and British Movies

\begin{tabular}{|c|c|c|c|c|c|c|c|}
\hline \multirow{2}{*}{ No. } & \multirow{2}{*}{ Strategies } & \multicolumn{2}{|c|}{$\begin{array}{c}\text { American Movies (AM) } \\
\text { t: 209 minutes }\end{array}$} & \multicolumn{3}{|c|}{$\begin{array}{c}\text { British Movies (BM) } \\
\text { t: 316 minutes }\end{array}$} \\
\cline { 3 - 8 } & No. & \% & $\begin{array}{c}\text { Per 100 } \\
\text { minutes }\end{array}$ & No. & $\%$ & $\begin{array}{c}\text { Per 100 } \\
\text { minutes }\end{array}$ \\
\hline 1 & Mitigated refusal & 11 & 11.96 & 2.10 & 12 & 13.04 & 2.29 \\
\hline 2 & $\begin{array}{c}\text { Reason/ } \\
\text { Explanation }\end{array}$ & 9 & 9.78 & 1.71 & 17 & 18.48 & 3.24 \\
\hline 3 & Indefinite reply & 1 & 1.09 & 0.19 & 3 & 3.26 & 0.57 \\
\hline 4 & Apology/ Regret & 2 & 2.17 & 0.38 & 2 & 2.17 & 0.38 \\
\hline 5 & Alternative & 1 & 1.09 & 0.19 & 1 & 1.09 & 0.19 \\
\hline 6 & Postponement & 2 & 2.17 & 0.38 & 1 & 1.09 & 0.19 \\
\hline 7 & $\begin{array}{c}\text { Repetition of } \\
\text { part of previous } \\
\text { discourse }\end{array}$ & 6 & 6.52 & 1.14 & 0 & 0.00 & 0.00 \\
\hline
\end{tabular}




\begin{tabular}{|c|c|c|c|c|c|c|c|}
\hline 8 & $\begin{array}{l}\text { Request for } \\
\text { additional } \\
\text { information }\end{array}$ & 4 & 4.35 & 0.76 & 3 & 3.26 & 0.57 \\
\hline 9 & $\begin{array}{l}\text { Set condition for } \\
\text { future or past } \\
\text { acceptance }\end{array}$ & 4 & 4.35 & 0.76 & 1 & 1.09 & 0.19 \\
\hline 10 & Wish & 1 & 1.09 & 0.19 & 0 & 0.00 & 0.00 \\
\hline 11 & $\begin{array}{l}\text { Promise to } \\
\text { comply }\end{array}$ & 1 & 1.09 & 0.19 & 0 & 0.00 & 0.00 \\
\hline 12 & Preparator & 8 & 8.70 & 1.52 & 2 & 2.17 & 0.38 \\
\hline & Total & 50 & 54.35 & 9.52 & 42 & 45.65 & 8,00 \\
\hline & $\begin{array}{l}\text { direct Refusal } \\
(\mathbf{A M}+\mathbf{B M})\end{array}$ & & 2 & \multicolumn{3}{|c|}{$\begin{array}{l}\text { Time Duration } \\
\qquad(\mathbf{A M}+\mathbf{B M})\end{array}$} & $\begin{array}{c}525 \\
\text { minutes }\end{array}$ \\
\hline
\end{tabular}

As seen from the table, American movies use all indirect refusal strategies by Félix-Brasdefer. Mitigated refusal is the most common strategy used in American movies in giving refusal. This strategy was used 11 times (11.96\%) throughout the movies, followed by reason/ explanation was used 9 times $(9.78 \%)$ and preparator was used 8 times $(8.70 \%)$.

On the other hand, the British table shows that the most common strategy which occurred 17 times (18.48\%) in delivering refusal is reason/ explanation. Then, the second place which the most frequently used in these movies is mitigated refusal. This strategy is used 12 times (13.04\%) when the movies are running. Different from the American movies, the British movies only use 9 out of 12 indirect refusal strategies by Félix-Brasdefer. The sections below discuss and analyse the refusals in terms of their indirectness.

\section{Mitigated Refusal}

Mitigated refusal is the most common indirect refusal strategy found in the American movies $(R V$ and We're the Millers). This part discusses refusals in which the interlocutor expresses the hedges to reduce the negative effect of being refused. The kinds of hedge are mental predicates (to think, to believe), adverbs (unfortunately), or degree modifiers (a little, somewhat). There are 11 mitigated refusal strategies found in the American movies and 12 utterances which contain the hedges used by the British movies.
The used of mitigated refusal strategies are shown here.

(1) $00: 51: 13,100 \rightarrow 00: 51: 38,600$ (AM.RV \#1.20)

After driving on for few hours to Colorado, $B o b$ and his family decided to park their $R V$ in Utah (a state in the western United States), take a rest, and make lunch. When Jamie (Bob's wife) wanted to turn on the oven, unexpectedly she found a gang of raccoons were in the oven. Bob and his family felt shock and quickly went out from the RV. Bob bravely attacked those raccoons away from their RV but it did not work anything. A gang of raccoons were still in their $R V$. Bob got a new plan. He tried to find out a kind of toxic (stick bomb) and set it off in the RV to scare those raccoons away. It was successfully working but Bob forgot to read out the indication before throwing it over to those raccoons. Consequently, they had to wait for the smell of the toxic off for up to six hours. Jamie (Bob's wife), Cassie (Bob's daughter), and Carl (Bob's son) were getting hungry. They talked to Bob that they were starving and wanted to look for pizza for dinner. Jamie gave a little suggestion to go to the bar that they passed on the way to Utah. Badly, Bob did not have the same idea and refused to go out there. 
Jamie : What about that bar we passed on the way up here?

Cassie : Yeah, Dad, pizza

Carl : And a roof.

Bob : No, it's dark out there. Besides, those raccoons could be waiting.

Carl : Hey! I can see it. It's just down there. Come on, I'm starving.

Jamie : Bob?

Bob : I think it's a bad idea. (Bob does not move out from his chair)

Bob's refusal can be classified as a mitigated refusal. In response to Jamie, Cassie and Carl's suggestions, Bob says I think it's a bad idea. Bob produces refusal by modifying the hedge which reduce the negative effects. He used mental state predicates (to think, to believe) to mitigate the refusal. This utterance mitigates the head of refusal I think so that it sounds more polite than just saying it without a hedge.

\section{Reason/Explanation}

Reason/explanation strategy is the most frequently used by the British movies (Chalet Girl, Cuban Fury, and Hot Fuzz). Giving reason/ explanation is one of the way interlocutors use to indirectly refuse offers, invitations, requests and suggestions. The reason/explanation shows a general or detail information why the interlocutor cannot fulfil the speaker's demand. Here is the example of 'reason/explanation' strategy.

(2) 00:44:32,400 $\rightarrow 00: 44: 36,500$ (AM.RV \#2.18)

In order to escape from the Gornicke freakfamily breakfast invitation, Bob and his family had to be an early riser. That morning, they could successfully get away earlier but in the middle of their trip, they were out of gas. Bob parked his RV in a gas station and quickly ran to find out the toilet. Unfortunately, a little problem happened, the $R V$ was rolling away. Suddenly, the Gornicke appeared in a gas station and helped them. After helping Bob's family, the Gornicke kindly tried to re-invite Bob and his family to have breakfast with them. Again and again, Bob and his family refused that invitation by explaining that they had breakfast.

Travis: So you folks wanna join us for breakfast?

Bob : We-

Jamie : Ate

In the dialogue above, Travis re-invites Bob and his family to have breakfast together in a restaurant around the gas station. Bob and Jamie refuse Travis' breakfast invitation by making a lie with detail information that they had already breakfast. This strategy is used in order to make Travis and his family might not get angry or feel sad of being refused twice.

\section{Indefinite Reply}

Indefinite reply strategy to refuse an invitation, request, offer, or suggestion often shows uncertain messages, vague answers, or undecided purposes. The part ofrefusals and the outcomes of the interaction are left open. It could make the interlocutor confused, whether it will be accepted or not. There are four indirect refusals which are identified as indefinite reply strategy found in the American and British movies. Here is the example from the movie conversation in terms of indefinite reply.

(3) $00: 36: 20,9208 \rightarrow 00: 36: 26,847$ (AM.WM \#3.15)

David was being robbed a week before and unable to pay his debt to his boss. As punishment, David was ordered by his boss to move in a huge shipment of Marijuana into the U.S. from Mexico. To reduce his criminal action from police officers, he recruited a broke stripper Rose, a homeless Casey, and his neighbour room Kenny to join him and pretend to be a family who wanted to take a holiday. On their way going back to U.S., they were stopped by a police officer who saw them just exited from the weed distribution. They had to pay the police officer; unfortunately they did not have any 
money. The police officer gave them an alternative, paid him, or followed his wish. David asked and convinced Kenny to grant the wish for saving their life from a gay police officer.

David : This is your chance to be the hero.

Kenny: I don't know, David. (He does not make any action)

David : Don't do it for me. Don't even do it for you.

Do it for the girls. For Rose and Casey.

Because, believe me, they won't last two days in a Mexican prison.

Example above illustrates the use of indefinite reply strategy. It is because the way Kenny gives a response to David's suggestion by saying I don't know, David that leaves his answer undecided. Kenny cannot make a decision whether he will do it or not because at that time, the situation is getting pressed him. However, by saying this indefinite reply, it can be seen that he prefers to not fulfil in David's suggestion.

\section{Apology/Regret}

This part discusses expressing regret or asking for forgiveness in indirect refusals which is used to show that the interlocutor feels sorry to refuse the speaker's invitation, offer, request, or suggestion. There are four utterances found in RV, Chalet Girl, and Hot Fuzz movies which are identified as apology/ regret strategy. Example from the data is displayed below.

(4) $00: 32: 48,700 \rightarrow 00: 32: 56,800$ (AM.RV \#4.15)

As a punishment of changing their family holiday from Hawaii to Colorado, Cassie's dad had a job as a family-chef. He had to cook dinner through their holiday. Because of Cassie's dad could not cook, as his responsible he invited his family to attend a dinner invitation from the Gornicke (the first family he had just known in the RV Park). The chef served meat as main course but unfortunately Cassie could not eat meat.
Chef : There you go, little lady.

Cassie : Oh, I'm sorry, I don't eat meat.

In the conversation above, the use of 'I'm sorry' by Cassie is identified as apology/regret strategy. Cassie uses this strategy for showing her apology and respect to the chef that may be open for polite utterances. The most important of delivering "sorry" is to minimize the negative effect of the chef being refused, such as hurting his feeling or misunderstanding.

\section{Alternative}

The interlocutor uses this strategy to suggest alternatives and possibilities when refusing an invitation, an offer, a request, or a suggestion. The purpose of delivering this strategy is to minimize the offense and take a mutual agreement between the speaker and interlocutor. An example of alternative strategy is as follow.

(5) 01:07:05 $\rightarrow$ 01:07:16 (AM.RV\#5.22)

To show his thankfulness to Bob as he helped to save Laird' face and Todd's big project with Bob's attractive-successful presentation to Alps Factory, Todd asked Bob to stay awhile, spend time with him and celebrate their successfulness. Badly, Bob had to go back soon before his family realized that the reason behind the changing of their family holiday's schedule from Hawaii to Colorado was not for holiday but rather for Todd's big project.

Todd: What's your hurry?

Why don't you stay and bask in my gratitude?

Bob : I gotta get the RV back right now, Todd or I have to pay for a full day. (He is walking to his RV)

Todd : Well, just picture me hugging you

In an example (5), Bob is refusing Todd's suggestion by providing an alternative strategy that shows the possibilities if he chooses to stay with Todd. By uttering I gotta get the RV back right now, Todd 
or I have to pay for a full day; Bob tries to tell another action that will be happened if he accepts Todd's suggestion. This strategy is applied to reach the mutual agreement between Bob and Todd.

\section{Postponement}

Postponement indirect refusal strategy is employed to implicitly delay refusal to an offer, a suggestion, an invitation, or even a request at that time. This strategy aims at putting off or delaying the response or just distracting the speaker's attention away from the refusal. The researcher only found three utterances which contain postponement strategy in each group movies. The example of 'postponement' is presented here.

(6) $00: 10: 34,500 \rightarrow 00: 10: 50,700$ (AM.RV\#6.9) As a consequence of changing his family holiday schedule from Hawaii to Colorado for his office's big project, Bob got some complaints from his family especially his wife. Jamie as a house wife who always spent her time with their children needed refreshment such as taking a holiday to Hawaii. Unfortunately, Bobfelt impossible to fulfil his wife's wishes that time. To make his wife stop complaining, he tried to indirectly refuse his wife request by putting over his family schedule to Hawaii at Christmas Season.

Bob : This way, we can spend time with them.

Jamie : You need to spend time with them. I spend nine hours a day with them. And I want Hawaii.

Bob : All right, we'll go to Hawaii. At Christmas. Then it will just be us and a lot of Jewish people. We'll have all the ham to ourselves.

In the conversation above, Bob as the interlocutor uses this strategy to delay the response. On this example, he thinks that it is impossible to take a holiday to Hawaii that time, so he refuses it by postponing their holiday schedule to Hawaii at Christmas Season. It indicates that he will release their family holiday schedule to Hawaii in the future.

\section{Repetition of Part of Previous Discourse}

When this strategy is used, the interlocutor purposes to distract the speaker's attention away by repeating some parts the discourse which represents the speaker's invitation, offer, suggestion, or request. Moreover, repeating part of the speaker's utterance will give time to the interlocutor to think about a more appropriate excuse. Six refusals from the American movies ( $R V$ and We're the Millers) were found expressed with this strategy. An example of this strategy is shown below.

(7) $00: 34: 04,560 \rightarrow 00: 34: 17,925$ (AM.WM \#13.12)

After successfully taking out a huge shipment of Marijuana from secret weed distribution, on their way going back to U.S., David and his fake family were stopped by a police officer who saw them just exited from that secret weed distribution. As their consequence, they had to pay the police officer to make them free and safe. Therefore, David tried to keep calm and pretended that he had much money. Unfortunately, David did not have any money; he and his fake family were in suppressed and dangerous situation that time.

David : This is what I'm talking about. Great! How much we talking? $100 ? 200$ ?

Police Officer: One thousand.

David : A thousand?

Police Officer: Hmm-mm

David : What, are you buying a house down here? It's a lot. Um, we don't have that sort of cash on us right now.

As presented above, David as the interlocutor uses repetition of part of previous discourse strategy to implicitly waste time to think of an appropriate excuse to the police officer. David shows by pretending that he has interest in the money that he should pay for the police officer. 


\section{Request for Additional Information}

The interlocutor uses this strategy to ask information that has not been previously mentioned by the speaker in his invitation, request, offer, or suggestion. This strategy is aimed to temporarily show a little interest in both the interlocutor and his/ her utterance, but still refuse. From 92 refusal expressions found in the movies, seven refusals were expressed with the strategy of request for additional information. The example of this strategy is displayed below.

(8) 01:00:13,880 $\rightarrow$ 01:00:25,329 (AM.WM \#8.19)

David rented an RV to go to Mexico. His RV suddenly stopped in the middle of nowhere. It was broken because David drove the $R V$ above speed limited. Luckily, David and his fake family (Rose, Casey, and Kenny) were helped by the Fritzgeralds (father-mother-a daughter). David's $R V$ was towed to the mechanic. Unfortunately, the mechanic was closed and will be opened the next morning. The Fritzgeralds invited them to make camp with them that night. Actually, they were doubtful to accept an invitation from somebody that he had known. Yet, there was no choice, they finally accepted it. Kenny and Melisa (the Fritzgeralds daughter) fell in love at first sight. After having camp-fire games, Melissa asked Kenny to go to the back of her RV to have a short-conversation before going to sleep. Melisa's gesture was shown that she wanted to be kissed by Kenny. Unfortunately, Kenny felt unconfident to express his confession to Melissa. Kenny just gave to Melisa a good night hug. David, Rose, and Casey watched and felt sympathy to the innocent Kenny. Rose spontaneously asked David to give the following suggestion to Kenny and amuse him.

Rose : That poor kid. Well, you should go talk to him.

David : Who?

Rose : I said you should go. Well, who do you think?

\author{
David : Me? What the hell am I gonna \\ say? \\ Rose : Talk to him about guy stuff. \\ David : Jesus fucking Christ. Oh no. (He does \\ not follow Rose's demand)
}

The example above shows that David refuses to Rose's suggestion. In the beginning of his refusal, he says "Who?" means that he has no idea about who is Rose's implicitly mentioned. After that, he also asks "Me? What the hell am I gonna say?" which indicates that he wants more explanation about what he should tell to Kenny. All questions show that he is not interested in and refuses to Rose's suggestion.

\section{Set Condition for Future or Past}

\section{Acceptance}

The interlocutor uses Set Condition for Future or Past Acceptance strategy as an indirect refusal to an invitation, an offer, a suggestion, or a request by setting an imaginary condition which acceptance would occur in the future or would have occurred in the past. There are five refusals were expressed with this strategy. Four refusals were found in $R V$ and one in Chalet Girl. An example of this strategy is as follows.

(9) $00: 35: 13,900 \rightarrow 00: 35: 30,200$ (AM.RV \#9.16)

The Gornicke felt really happy and honoured because of Bob and his family kindly accepted his dinner's invitation that night. It caused him wanted to invite Bob and his family again to have breakfast together the next morning.

Travis : Hope we see you again. How about breakfast tomorrow?

Cassie : Bagels and deer testicles?

Travis : Oh, yeah, she's funny, just like you.

Bob : We'd have breakfast, but we're early risers.

Travis : Well, us too. 6 a.m. work for you?

Jamie : We'll be long gone by then.

Bob : Yeah, trust us. (Bob and his family do not attend the invitation) 
In the conversation above, Bob refuses Travis's invitation about having breakfast together the following morning by saying we'd have breakfast. The sentence above indicates that he cannot fulfil the Travis' invitation that time.

\section{Wish}

This strategy states a wish or desire in the refusal. It is often applied as polite refusal responses to express the willingness of the speaker to accept an invitation, an offer, a suggestion, or even a request. It helps to reduce the negative effects of a direct refusal. There is only one refusal expressed with this strategy which is found in the group of American movies. The example of this strategy is shown below.

(10) 00:28:50,900 $\rightarrow$ 00:29:13,600 (AM.RV \#10.14)

Bob's rented-RV had tank sewage's problem. He and his son Carl went to a flume to throw up the waste. Bob did not understand how to throw that waste away. Suddenly, a stranger named Travis came and helped him. For welcoming party to Bob and his family, Travis invited them to have dinner with him and his family that night. Unfortunately, as a Bob's punishment of changing Hawaii to Colorado for holiday, he had to cook dinner through their holiday. He could not attend on Travis's invitation for having dinner.

Travis : Why don't you come on over? Tuesday's meat.

Then afterwards, we can sit around and watch Ernest Goes to Jail.

Bob : It is funny. Well, it's a classic.

Travis : Yeah, we'll make a whole night of it. Bob : I wish I could.

I promised my family I'd make my special dish kebob.

Travis : Oh, that's good. Well, another time, then.

From the conversation above, it can be seen that Travis invites Bob and his family to have dinner with his family that night, but Bob cannot accept Travis' invitation. Bobuses the keyword of 'wish' strategy "I wish I could". It means that he actually wants to have dinner with Travis' family, but he cannot fulfil the invitation because he has promised his family for making dinner meal that night.

\section{Promise to Comply}

By expressing this strategy, the interlocutor does not want to make any commitment in accepting the speaker's request, invitation, offer, or suggestion although she/he might fulfil it in the future. There is only one refusal expressed with this strategy which is found in We're the Millers movie. The example of this strategy is presented below.

(11) 00:47:25,600 $\rightarrow$ 00:47:30,769 (AM.WM \#11.17)

David and his fake-family suddenly stopped in the middle of nowhere. His rented-RV was broken because he drove above the speed limited. Luckily, they were helped by the Fritzgerald. They helped to tow David's $R V$ to the mechanic. They asked David's family to ride in with them. Edith looked and interested in David's little baby was held by Rose. Actually, David's baby was a pack of Marijuana; they just pretended to be a perfect family by holding a baby. Unfortunately, as in her entire life Edith obsessed to have a baby, she really wanted to hold that fake baby.

Edith : I'm holding that baby.

Rose : Edie, you will, I promise, but it's nap time for LeBron.

(She still holds her baby)

By using "I promise" it could be identified that Rose uses 'promise to comply' as her indirect refusal strategy. She actually does not want to make any commitment about giving her fake baby to Edith. In order to soften her refusal, Rose shows her uncertainty when refuses Edith's request and also avoids of making promise with Edith. 


\section{Preparator}

Preparator strategy is functions to soften the negative effect of upcoming refusal. An upcoming refusal can be identified by looking at the utterances which contain an expression of positive opinion or feeling about the interlocutor's demand and also pause fillers (uhh/well/oh/uhm) as a sign to give a refusal. American movies use this strategy eight times to refuse an offer, an invitation, two requests, and four suggestions. Here is an example of preparator strategy.

(12) $00: 43: 07,300 \rightarrow 00: 43: 16,700$ (AM.RV \#12.17)

To avoid the Gornicke breakfast's invitation, Bob and his family went out from RV Park earlier. They could successfully get away from the Gornicke but in the middle of journey, they were out of gas. Bob parked his RV in gas station and found out the toilet. Unfortunately, a little problem happened, the $R V$ was rolling away because Bob forgot to interlock his RV's parking gear and set an emergency brake. Directly, the Gornicke appeared in the gas station and helped them. As their greeting to Bob and his family, Mary Jo (Travis's wife) offered to tell a story to Bob. Mary Jo : Wanna hear about the time... ...Jesus saved us from a tornado? It's great.

Bob : I'd love to, but I was in the little boys' room...

...taking care of business when Carl interrupted...

...but Jamie would love to hear it.

(He runs and looks for toilet)

In the dialogue above, it can be seen that to refuse Mary Jo's offer to tell a story, Bob firstly answers Mary Jo's offer about having interested in Mary Jo's story by saying I'd love to. In fact, Bob's refusal above contains a sign to Mary Jo that he will refuse her offering. Bob creates a refusal started with a preparator I'd love to in order to soften her upcoming refusal might give to Mary Jo.

\section{CONCLUSION}

This research has investigated indirect refusal in two American and three British movies entitled $R V$, We're the Millers, Chalet Girl, Cuban Fury, and Hot Fuzz. The results of the research show that out of 92 refusal utterances, 50 were found in the American movies and 42 in the British movies. Based on the findings, the American movies use all the indirect refusal strategies. Mitigated refusal is the most common strategy used in the American movies. This strategy was used 11 times $(11.96 \%)$ throughout the movies, followed by reason/ explanation which was used 9 times $(9.78 \%)$ and preparator was used 8 times $(8.70 \%)$ during the movies. On the other hand, the British movies results show that the most common strategy which occurred 17 times (18.48\%) in delivering refusal is reason/ explanation. Then, the second place of the most used in these movies is mitigated refusal. This strategy is used 12 times (13.04\%) when the movies are running. Different from the American movies, the British movies only use 9 out of 12 indirect refusal strategies by Félix-Brasdefer (2008, 74-79).

These results seem to suggest that the American and the British have their own ways in delivering refusals. To minimize the negative effects of being refused the Americans tend to hedge the refusals for making the utterances sounds more polite than just saying it without hedge. Meanwhile, the British tend to explain why they cannot fulfil the interlocutor's demands. They thought by providing excuses, reasons, or explanations they could reduce the negative effect of the refusal.

The results of this research are quite different from the result of CARLA (Center for Advanced Research on Language Acquisition) 2014. According to $C A R L A$, the most common indirect refusal strategy used by the Americans is preparator. Meanwhile, the results of this research show that preparator strategy is the third ranking of the common used by the Americans. For British refusals, CARLA and this research have the same results that reason/ 
explanation strategy is the most commonly strategy of British refusals.

This research focuses only on the identification and classification of indirect refusal strategies in American and British movies. Since the scope of this research is very limited, further research on the same topic is highly suggested to support the results of this research. There are also other interesting scopes of studies such as comparing American and British refusal from positive-negative politeness aspect that can be analysed in pragmatic studies or cross cultural aspect that can be analysed in sociolinguistic studies.

\section{BIBLIOGRAPHY}

Burhanuddin, Ahmad. 2008. A Comparative Study on Refusals in English by Indonesian Learners and Native Speakers of English. Universitas Gadjah Mada. Unpublished graduating paper.

Cambridge Advanced Learner's Dictionary. 2008. "refusal". Cambridge: Cambridge University Press.

CARLA (Center for Advanced Research on Language Acquisition). 2014. "Pragmatics/ Speech Acts: Refusals". Accessed on October 13th, 2014. http://www.carla.umn.edu/ speechacts/refusals/index.html.

Charismawati, Arie. 2014. Positive and Negative Politeness of Refusals in Three American Drama Movies. Universitas Gadjah Mada. Unpublished graduating paper.

Diffen. 2014. "American English vs. British English”. Accessed on October 29th, 2014. http:// w w w.diffen.com/difference/ American_English_vs_British_English.

Félix-Brasdefer, J. César. 2008. Politeness in Mexico and the United States: A Contrastive Study of the Realization and Perception of Refusals. Amsterdam: John Benjamins.
Griffiths, James. 2014. Cuban Fury. Movie: Studio Canada.

Muliawati, Nabila. 2014. Indirect Refusals Strategies in Three American Movies. Universitas Gadjah Mada. Unpublished graduating paper.

Rahmatika. 2013. Refusals as Used in Drama Movies in English. Universitas Gadjah Mada. Unpublished graduating paper.

Sonnenfeld, Barry. 2006. $R V$. Movie: Columbia Pictures.

Subscene. 2014. Chalet Girl: IFC Films. Accessed on September 15th, 2014. http:// subscene.com/subtitles/chalet-girl/english/ 479304.

Subscene. 2014. Cuban Fury: Studio Canada. Accessed on September 16th, 2014. http:// subscene.com/subtitles/cuban-fury/english/ 929181.

Thurber, Rawson M. 2013. We're the Millers. Movie: Warner Bros Pictures.

Traill, Phil. 2011. Chalet Girl. Movie: IFC Films.

Wright, Edgar. 2007. Hot Fuzz. Movie: Universal Pictures.

Yule, George. 1996. Pragmatics. Oxford: Oxford University Press. 